\title{
Child Abuse in India- Time for introspection
}

\section{S Girdhar}

\section{Citation}

S Girdhar. Child Abuse in India- Time for introspection. The Internet Journal of Health. 2008 Volume 9 Number 2.

DOI: $\underline{10.5580 / 390}$

\section{Abstract}

Sir,

Child abuse is very widespread familiar phenomenon, a shocking characteristic of modern world! In today's scenario, it has become a very common incident when the innocent, defenseless and helpless child goes through physical or emotional ordeal.

Child abuse is violation of basic human rights of a child.

Child abuse is the physical or psychological /emotional mistreatment of children.CDC has defined child abuse as an act or commission or omission by a parent or other caregiver that results in harm, potential for harm or threat of harm to a child1

In India there's a tradition of denying child abuse. It doesn't happen here is what we normally say. But by remaining silent, we have aided and abetted the abuse of children.

In India, the abuse is carefully hidden from outsiders by both abusers and victims. The victims are afraid to speak about their abuse because of the shame it will bring to them. At least in the Western world, the victims today have courage to speak out about the abuse.

Traditionally in India, the responsibility of care and protection of children has been with families and communities. While the constitution of India guarantees many fundamental rights to the children, the approach to ensure the fulfillment of these rights is more need based rather than rights based. The transition to rights based approach is still needed.

For the first time in India the study regarding child abuse was conducted in 13 states. The findings of this study will help in the understanding of all stakeholders including families, communities, civil society and state.
In National study done by Ministry of Women and child development supported by UNICEF in 13 states of India on child abuse revealed alarming results on child abuse 2 . This is the first time the government has done such an exhaustive survey on the controversial issue of child abuse. It revealed that across different kinds of child abuse, it is young children i.e. 5-12 year age group children who suffers the most. Two out of every three children were physically abused. $53.22 \%$ children reported having faced one or more forms of sexual abuse. $21.90 \%$ child respondents reported facing severe forms of sexual abuse and $50.76 \%$ other forms of sexual abuse. Every second child reported facing emotional abuse.

Child sexual abuse is probably the one social evil that is overlooked in India, a crime that people consistently pretend to ignore.

The gravity of the situation demands that the issue of child abuse to be placed on National agenda.

Despite the many legislations in India on several forms of child abuse, there are still gaps in the legal provisions related to child abuse.

It is absolute necessary to alert Government, civil society and citizens to play a more active role in promotion, respect and appreciation of the rights of the child.

Merely acknowledging this on International Day for the rights of the child - 19 th November is not sufficient. What is needed - is continuous development of law and civil society responses to this critical problem. Now we have groundbreaking data on child abuse. It is the time people should wake up for protection of children's rights.

Legal provisions are there but there is lack of system of awareness and information - which has made this problem challenging. 
Child abuse is a matter that needs utmost attention since it involves the future generation of his world. This could be prevented by having seminars for parents which would invoke them to take care of their children more.
Change may be long in coming but we need to make a beginning somewhere if we claim to be a civilized society.

\section{References}

1. http:// www.cdc.gov/ncipc/dvp/CMP/CMp-surveillence 2. http://wcd.nic.in/childabuse.pdf 


\section{Author Information}

Sangeeta Girdhar, MBBS, MD

Assistant Professor Community Medicine, Dayanand medical college \& hospital, ludhiana. India 